\title{
Evaluasi sistem otomasi IBRA V6 di Perpustakaan SDIT Luqman Al- Hakim Internasional Yogyakarta
}

\author{
Nurul Alifah Rahmawati \\ Program Studi Interdisciplinary Islamic Studies UIN Sunan Kalijaga Yogyakarta \\ Jl. Laksda Adisucipto, Caturtunggal, Depok, Kabupaten Sleman, Daerah Istimewa Yogyakarta 55281 \\ E-mail: nurulalifah301@yahoo.com
}

Received: October 2017; Accepted: May 2018; Published: June 2018

\begin{abstract}
Implementation of automation systems in the library make it easy access for students and can improve the quality of its services. SDIT Luqman Al-Hakim International Yogyakarta's Library has implemented an IBRA V6 automation system in a library services. However, this library still often do the service manually although it is automated. Therefore, evaluation of IBRA V6 automation system in library is needed. This study aims to evaluate the performance of IBRA V6 based library automation system on the circulation section of SDIT Library Luqman AlHakim Internasional Yogyakarta. The method of research is a qualitative approach that focuses on the process of circulation, borrowing and return collection. Data collection techniques use observation, interview and documentation. This research is based on service performance theory then formulated with theory of success model of DeLone \& McLean system which got 5 indicator from 3 Aspect that is supporting facilities, system quality, operational, service and resultant impact. Of the five indicators are obtained the result that the first indicator of supporting facilities was adequate, but the space was very tightso that the overall service is less. As for other indicators obtained good results, effective and efficient. So the conclusion researchers that the performance of IBRA $V 6$ based library automation system on the circulation process in the library of SDIT Luqman Al-Hakim International is good.
\end{abstract}

Keywords: Evaluation; IBRA V6 library automation system; Circulation

\begin{abstract}
Abstrak
Perkembangan teknologi informasi memberikan berbagai kemudahan kerja dalam segala bidang termasuk perpustakaan. Penggunaan teknologi informasi disebut dengan otomasi perpustakaan. Kegiatan manual di perpustakaan semakin hari semakin ditinggalkan karena adanya perkembangan teknologi informasi untuk memenuhi kebutuhan pemustaka. Perpustakaan SDIT Luqman Al-Hakim Internasional Yogyakarta telah menerapkan sistem otomasi berupa IBRA V6 dalam pelayanan perpustakaannya. Namun, perpustakaan ini masih sering melakukan pelayanan secara manual padahal sudah terotomasi. Oleh karena itu dibutuhkan evaluasi terhadap sistem otomasi IBRA V6. Penelitian ini bertujuan untuk mengevaluasi kinerja sistem otomasi perpustakaan berbasis IBRA V6 pada bagian peminjaman dan pengembalian (sirkulasi). Metode penelitiannya kualitatif yang memfokuskan pada proses sirkulasi bagian peminjaman dan pengembalian koleksi. Teknik pengumpulan data menggunakan teknik observasi, wawancara serta dokumentasi. Penelitian ini didasarkan pada teori kinerja layanan kemudian diformulasikan dengan teori model kesuksesan sistem DeLone \& McLean yang didapat 5 indikator dari 3 Aspek yaitu sarana pendukung, kualitas sistem, operasional, layanan serta dampak yang dihasilkan. Dari ke-lima indikator tersebut diperoleh hasil bahwa indikator pertama yaitu sarana pendukung sudah memadai hanya saja ruangannya yang sempit sehingga pelayanan keseluruhan kurang maksimal. Sedangkan untuk indikator yang lain diperoleh hasil yang baik, efektif dan efisien. Sehingga kesimpulannya adalah kinerja sistem otomasi perpustakaan berbasis IBRA V6 pada proses sirkulasi di perpustakaan SDIT Luqman Al-Hakim Internasional baik.
\end{abstract}

Kata Kunci: Evaluasi; Sistem otomasi perpustakaan IBRA V6; Sirkulasi. 


\section{PENDAHULUAN}

Teknologi dan komunikasi informasi, yang disebut juga dengan teknologi informasi atau dikenal juga dengan telematika, mulai digunakan di berbagai perpustakaan, khususnya perpustakaan besar dari berbagai perpustakaan (Sulistyo-Basuki, 2010). Maka, perpustakaan memerlukan teknologi informasi untuk menunjang kegiatan-kegiatan di perpustakaan guna melayani pemustakanya. Adanya teknologi informasi ini, nyatalah bahwa ada bagian kerja yang dapat dipermudah dengan bantuan alat ataupun teknologi. Kegiatan ini disebut dengan otomasi perpustakaan. Kegiatan manual di perpustakaan semakin hari semakin ditinggalkan karena adanya perkembangan teknologi informasi untuk memenuhi kebutuhan pemustaka. Oleh karena itu, kegiatan manual ini secara tidak langsung harus dialihkan dengan menerapkan otomasi. Menurut Feather dalam Lasa (2013) penerapan otomasi pada perpustakaan lebih tepat apabila disebut dengan teknologi informasi. Pemanfaatan teknologi informasi dapat meningkatkan kualitas layanan baik kecepatan maupun kualitas informasi yang diberikan untuk mengelola atau menjalankan operasional perpustakaan (Dana, Samosir, \& Widiyasa, 2015).

Beberapa kajian literatur dalam penelitian ini antara lain penelitian yang dilakukan oleh Saputra, Cahyadi, \& Kridalaksana (2016) yang berjudul Sistem Otomasi Perpustakaan dengan Menggunakan Radio Frequency Identification (RFID). Selanjutnya penelitian yang dilakukan oleh Azwar (2015) yang berjudul Penerapan Sistem Otomasi di Perpustakaan Fakultas Adab dan Humaniora UIN Alauddin Makassar. Penelitian tersebut membahas mengenai sistem otomasi yang diterapkan di perpustakaan. Meskipun sistem yang digunakan berbeda-beda, namun tujuannya sama yaitu untuk memudahkan layanan di perpustakaan. Hal ini meliputi input atau masukan, proses dan hasil keluarannya.

Peningkatan citra dan kinerja sebuah perpustakaan dapat dilakukan dengan cara penerapan teknologi informasi secara langsung dan tidak langsung secara benar dan tepat Sutarno (2006) dalam Siregar (2017). Penggunaan teknologi informasi ini dapat memberikan kemudahan akses bagi siswa dan meningkatkan kualitas pelayanan di perpustakaan sekolah. Salah satunya yaitu pelayanan sirkulasi. Menurut Qolyubi (2007) dalam Hasanah (2010) layanan sirkulasi merupakan salah satu jasa perpustakaan yang pertama kali berhubungan langsung dengan pengguna perpustakaan, sehingga kualitas pelayanannya pun perlu ditingkatkan dan disesuaikan dengan perkembangan teknologi terkini. Kualitas pelayanan merupakan suatu hal yang sangat penting untuk diwujudkan, karena merupakan ujung tombak dalam dunia perpustakaan (Rodin, 2015). Pelayanan sirkulasi yang diberikan pada pengguna sangat berkaitan erat dengan baik tidaknya suatu perpustakaan. Kegiatan layanan sirkulasi meliputi peminjaman, pengembalian, pemungutan denda, pendaftaran anggota, baca ditempat, penagihan, pembuatan statistik dan hubungan masyarakat. Dengan sistem otomasi yang diterapkan di perpustakaan, pelayanan sirkulasi di perpustakaan dapat dilakukan dengan lebih efektif dan efisien.

Penggunaan sistem otomasi perpustakaan sudah menjadi keharusan bagi perpustakaan dalam upaya meningkatkan layanan yang berkualitas bagi penggunanya. Selain itu, semakin mudahnya akses terhadap internet yang dapat digunakan untuk keperluan komunikasi dan informasi oleh masyarakat kapan saja dan di manapun mereka berada menjadi alasan untuk mengembangkan sistem perpustakaan yang dapat diakses dengan mudah oleh siapapun dan dimanapun pengguna itu berada. Sehingga informasi yang dimiliki oleh suatu perpustakaan dapat dengan 
mudah disebarluaskan kepada masyarakat (Rahmawati, 2015). Dengan demikian sistem otomasi perpustakaan memang seharusnya telah diterapkan penggunaannya tidak hanya di perpustakaan Perguruan Tinggi, Perpustakaan Umum maupun perpustakan khusus saja tetapi hingga perpustakaan sekolah dasar yang memiliki pemustaka dengan umur dibawah 12 tahun. Otomasi akan memperingan kerja pustakawan dan memudahkan pemustaka dalam memanfaatkan perpustakaan (Purwanto, 2015).

Salah satu perpustakaan yang telah menerapkan otomasi yaitu perubahan dari manual ke otomasi ialah Perpustakaan Adiba SDIT Luqman Al-Hakim Internasional. Hal yang paling dominan dari penerapan otomasi di perpustakaan ini ialah dalam kegiatan sirkulasinya khususnya bagian sirkulasi. Perpustakaan ini menggunakan sistem otomasi perpustakaan yang berbayar yaitu IBRA V6. IBRA V6 (Integrated Library Information System) adalah paket program manajemen database yang dirancang dan dibuat dengan tujuan untuk mendukung serta menunjang layanan administrasi dan sistem informasi pada perpustakaan (Modul Teratama IBRA V6, 2014). Selain mempunyai banyak keuntungan dengan adanya sistem otomasi ini, masih banyak juga kendala yang dihadapi dalam pelayanan antara lain, kurangnya SDM karena hanya ada satu orang yang melayani pemustaka dalam berbagai macam pelayanan, ruangan yang sempit sedangkan koleksi semakin bertambah juga menjadi kendala dalam pelayanan, serta masih adanya ketergantungan dengan pihak Teratama sehingga jika terjadi eror pada sistem, pustakawan harus mengundang pihak IBRA karena tidak bisa memperbaiki sendiri, hal tersebut mengingat bahwa software IBRA adalah software yang berbayar atau bukan open source.

Permasalahan lain muncul khususnya dalam kinerja sistem otomasi pada proses sirkulasi ini yaitu masih seringnya menggunakan pelayanan sirkulasi secara manual meskipun sudah terotomasi dan meskipun tidak adanya mati listrik. Padahal Lasa (2009) mengatakan bahwa otomasi perpustakaan (library automation) ialah suatu proses atau hasil penciptaan mesin swatindak atau swakendali tanpa adanya campur tangan manusia dalam proses tersebut. Dari teori tersebut dapat disimpulkan bahwa dalam sistem otomasi perpustakaan sudah tidak menggunakan campur tangan manusia atau sudah tidak manual lagi dalam prosesnya. Namun di Perpustakaan Adiba SDIT Luqman Al-Hakim Internasional masih sering menggunakan proses secara manual padahal sudah terotomasi. Lalu bagaimanakah kinerja sistem otomasi yang digunakan khususnya dalam pelayanan sirkulasi yang masih manual, apakah hal ini termasuk dalam proses otomasi perpustakaan yang telah sesuai dengan teori otomasi perpustakaan? Ataukah terdapat kesalahan pada proses dan sistemnya? Oleh sebab itu, maka diperlukan suatu penelitian yang bertujuan untuk mengevaluasi kinerja sistem otomasi perpustakaan berbasis IBRA V6 pada bagian sirkulasi di Perpustakaan SDIT Luqman Al-Hakim Internasional Yogyakarta.

Untuk mengetahui apakah sistem telah berjalan dengan baik, dapat diketahui dengan beberapa model kesuksesan sistem. Model kesuksesan sistem informasi DeLone \& McLean dalam Jogiyanto (2007) dalam Wisudiawan (2015) antara lain: (1) Kualitas sistem (System quality) yang digunakan untuk mengukur kualitas sistem informasinya sendiri. Pengukuran-pengukuran untuk mengukur kualitas sistem informasi antara lain: kekinian data diusulkan (proposed data currency), waktu respon (response time), waktu pergantian (turn around time), keakuratan data (data accuracy), keandalan (reliability), kelengkapan (completeness), 
keluwesan sistem (system flexibility) dan kemudahan penggunaan (ease of use). (2) Kualitas informasi (Information quality) untuk mengukur kualitas keluaran dari sistem informasi. Beberapa item untuk mengukur kualitas informasi antara lain keakuratan informasi (information accuracy), ketepatwaktuan keluaran (output timeliness), keandalan (reliability), kelengkapan (completeness), relevan (relevance), ketepatan (precision) dan kekinian (currency). (3) Penggunaan informasi (informationuse) merupakan penggunaan keluaran suatu sistem informasi oleh penerima. Penggunaan informasi ini mengacu pada seberapa sering pengguna menggunakan informasi serta penggunaan informasi itu sendiri untuk apa. (4) Kepuasan pemakai (user satisfaction) merupakan respon pemakai terhadap penggunaan keluaran sistem informasi. Beberapa penelitian menemukan bahwa kepuasan pemakai berhubungan erat dengan sikap (attitude) dari pemakai terhadap pemakaian sistem informasi. (5) Dampak individual (individual impact) merupakan efek dari informasi terhadap perilaku pemakai. Dampak atau impact berhubungan erat dengan kinerja, yaitu meningkatkan kinerja individual pemakai sistem. Dampak (impact) dapat juga berarti mempunyai kontribusi terhadap pemakainya, pemahaman yang lebih baik terhadap pengambilan keputusan yang dilakukan, meningkatkan produktivitas dari pengambilan keputusan, merubah kegiatan dari pemakai atau merubah persepsi pemakai tentang pentingnya atau bergunanya sistem informasi. Dalam hal ini indikator yang akan diambil berhubungan dengan waktu yang dibutuhkan untuk menyelesaikan suatu tugas yaitu efisiensi dari penyelesaian tugas. (6) Dampak organisasi (organization impact) merupakan impact atau dampak dari informasi terhadap kinerja organisasi. Berkaitan dengan biaya efektivitas menyeluruh dari penerapan sistem informasi (Wisudiawan, 2015).

Menurut Sutarno (2006) dalam Siregar (2017) kinerja atau "performance" suatu perpustakaan merupakan sebuah gambaran atas keberhasilan atau pun kegagalan penyelenggaraan layanan perpustakaan. Beberapa alasan perlunya dilakukan pengukuran kinerja yaitu pengukuran kinerja dianggap cukup penting, karena kinerja adalah state of condition dari suatu pelaksanaan kerja dalam mencapai sesuatu, kondisi, dan perubahan yang diinginkan. Manfaat pengukuran kinerja yaitu untuk kepentingan pengelolaan perpustakaan seperti pengembangan jasa layanan informasi dan produk perpustakaan; pemetaan anggaran seperti anggaran pengembangan perpustakaan dan lainnya (Wakhid, Sitanggang, \& Saleh, 2016).

Untuk mengetahui apakah layanan berhasil atau mengalami kegagalan, maka diperlukan indikator-indikator yang telah ditetapkan sebelumnya. Adapun indikator-indikator tersebut meliputi: (1) Masukan (input), indikator ini dimaksudkan untuk mengukur sumberdaya perpustakaan, baik yang bersifat fisik (material) seperti koleksi, sarana prasarana, sumberdana serta perabotan, maupun yang bersifat nonfisik (immaterial) seperti kebijakan, peraturan dan perundang-undangan, dan sebagainya yang digunakan untuk melaksanakan kegiatan perpustakaan. (2) Proses (process), proses yang terjadi di perpustakaan adalah semua aktivitas yang terjadi atau dilakukan selama pelaksanaan kegiatan perpustakaan berlangsung dengan 
melibatkan semua unsur di perpustakaan. Proses tersebut diselenggarakan untuk mencapai target, sasaran dan tujuan akhir perpustakaan. (3) Luaran atau hasil (output), keluaran atau hasil yang akan dicapai oleh perpustakaan adalah terjadinya transfer atau alih informasi dari berbagai sumber di perpustakaan. Semakin banyak transaksi informasi, maka semakin besar manfaat atau hasil yang diperoleh. (4) dampak yang dihasilkan atau dirasakan (outcome), dampak yang dihasilkan antara lain: perpustakaan makin berkembang, tumbuhnya kesadaran masyarakat tentang pentingnya perpustakaan, tersebarnya informasi, ilmu pengetahuan dan teknologi, serta perubahan sikap atau perilaku pemakai perpustakaan.(5) pengaruh (impact), indikator ini memperlihatkan pengaruh yang ditimbulkan dari manfaat yang diperoleh dari hasil kegiatan. (6) keuntungan (benefit), keuntungan yang diperoleh dapat dirasakan oleh banyak pihak baik bagi perpustakaan, pengelola perpustakaan maupun pemakai. Keenam indikator tersebut merupakan alat atau tools yang dapat digunakan untuk mengukur keberhasilan atau kegagalan pembinaan perpustakaan, baik secara kualitatif maupun kuantitatif.

Berdasarkan model kesuksesan sistem dan indikator-indikator kinerja yang telah dijelaskan sebelumnya, maka seluruhnya dapat diformulasikan sebagai instrumen yang dapat digunakan untuk mengevaluasi kinerja sistem otomasi perpustakaan IBRA V6. Hal ini sesuai dengan tujuan dari penelitian yaitu untuk mengevaluasi kinerja sistem otomasi perpustakaan berbasis IBRA V6 pada bagian sirkulasi di Perpustakaan SDIT Luqman Al-Hakim Internasional Yogyakarta.

\section{METODE PENELITIAN}

Jenis penelitian ini ialah penelitian kualitatif dengan pendekatan studi kasus. Studi Kasus merupakan suatu serangkaian kegiatan ilmiah yang dilakukan secara intensif, terinci serta mendalam tentang suatu program, peristiwa, dan aktivitas, baik pada tingkat perorangan, sekelompok orang, lembaga, atau organisasi untuk memperoleh pengetahuan mendalam tentang peristiwa tersebut. Biasanya, peristiwa yang dipilih yang selanjutnya disebut kasus adalah hal yang aktual (real- life events), yang sedang berlangsung, bukan sesuatu yang telah lewat (Rahardjo, 2017). Informan dalam penelitian ini berjumlah dua orang, sehingga dipilih penelitian kualitatif yang dimaksudkan agar diperoleh hasil yang lebih mendalam mengenai masalah yang terjadi. Subyek penelitian ini adalah kinerja sistem otomasi perpustakaan, sedangkan obyeknya adalah pelayanan sirkulasi bagian peminjaman dan pengembalian koleksi dengan menerapkan sistem otomasi perpustakaan berbasis IBRA V6. Penelitian ini berlangsung pada bulan Februari-Maret 2016, di Perpustakaan Adiba SDIT Lukman Al-Hakim Internasional Yogyakarta, yang beralamat di Jl. Karanglo, Jogoragan, Banguntapan Bantul, Yogyakarta.

Dalam penelitian kualitatif, instrumen dalam penelitian adalah peneliti itu sendiri (Sugiyono, 2010). Oleh karena itu, sebagai instrumen peneliti juga harus divalidasi sejauh mana kesiapan untuk melakukan penelitian yang kemudian terjun ke lapangan. Validasi terhadap peneliti meliputi evaluasi diri mengenai pemahaman metode penelitian, 
penguasaan terhadap penelitian yang dilakukan, serta kesiapan dan bekal peneliti untuk terjun ke lapangan. Selain itu juga dibutuhkan alat bantu berupa indikator-indikator untuk mempermudah wawancara. Indikatorindikator dalam penelitian ini diperoleh dari teori tentang kinerja layanan perpustakaan yang dikemukakan oleh Sutarno (2006) dalam Siregar (2017) dan diformulasikan dengan teori DeLone \& McLean (D\&M IS Success Model) tentang kesuksesan sistem seperti yang telah dijabarkan dalam landasan teori pada bab II. Formulasi kedua teori tersebut bermaksud untuk mendukung atau menguatkan teori yang satunya dalam pemecahan masalah. Dengan mengacu pada kedua teori tersebut maka diperoleh indikator-indikator sebagai berikut:

Tabel 1

Indikator kinerja layanan perpustakaan dan kesuksesan sistem

\begin{tabular}{ll}
\hline Kategori/aspek & Indikator \\
\hline Masukan (input) & Sarana pendukung \\
Proses (process) & $\begin{array}{l}\text { Kualitas sistem } \\
\text { operasional }\end{array}$ \\
Luaran (output) & Layanan \\
Dampak (impact) & $\begin{array}{l}\text { Sesuatu yang } \\
\text { dihasilkan }\end{array}$ \\
\hline
\end{tabular}

Metode dan teknik dalam pengumpulan data yang dilakukan pada penelitian ini antara lain (1) Observasi, Sugiyono (2010) menyatakan bahwa teknik pengumpulan data dengan observasi digunakan bila penelitian berkenaan dengan perilaku manusia, proses kerja, gejala-gejala alam dan apabila responden yang diamati tidak terlalu besar. Pengamatan dilakukan dengan maksud peneliti dapat memahami dengan jelas proses sirkulasi dengan menerapkan sistem otomasi IBRA V6 di Perpustakaan Adiba SDIT Luqman Al-Hakim Internasional Yogyakarta.

Wawancara, ialah teknik pengumpulan data dimana pewawancara (peneliti atau yang diberi tugas melakukan pengumpulan data) dalam mengumpulkan data mengajukan suatu pertanyaan kepada yang diwawancarai (Sugiyono, 2010). Wawancara yang digunakan peneliti yaitu wawancara semistruktur. Jenis wawancara ini termasuk dalam kategori in-dept interview, dimana dalam pelaksanaannya lebih bebas dibandingkan wawancara terstruktur. Tujuan dari wawancara ini adalah untuk menemukan permasalahan secara lebih terbuka, dimana pihak yang diajak wawancara diminta pendapat dan ide-idenya (Sugiyono, 2010). Dalam metode ini wawancara dilakukan kepada Pustakawan yang menjadi user dari sistem otomasi perpustakaan ini dan Kepala Perpustakaan sebagai patron Perpustakaan Adiba SDIT Luqman AlHakim Internasional Yogyakarta. (3) Dokumentasi, peneliti menyelidiki benda-benda tertulis seperti bukubuku, majalah, dokumen, peraturanperaturan, notulen rapat catatan harian dan sebagainya dalam melaksanakan metode dokumentasi ini (Arikunto, 2010). Dokumentasi digunakan untuk melengkapi data yang dibutuhkan dalam penelitian. Peneliti melakukan metode dokumentasi dari sumbersumber antara lain modul tentang sistem otomasi IBRA V6, hasil penelitian tentang Perpustakaan Adiba SDIT Luqman Al-Hakim Internasional serta berbagai buku yang berhubungan 
dengan ilmu perpustakaan khususnya sistem otomasi perpustakaan.

Sementara itu, uji kredibilitas yang digunakan dalam penelitian ini yaitu perpanjangan pengamatan, triangulasi dan membercheck.

Perpanjangan pengamatan, peneliti kembali ke lapangan, melakukan pengamatan, wawancara lagi dengan sumber data yang pernah ditemui di Perpustakaan Adiba SDIT Luqman AlHakim Internasional. Dengan hal ini peneliti akan semakin akrab, semakin terbuka dengan informan sehingga tidak ada yang disembunyikan lagi dan data yang diperoleh semakin asli atau pasti kebenarannya. Lama perpanjangan penelitian ini disesuaikan dengan kebutuhan penelitian sampai mendapatkan data yang sudah jenuh. Dalam penelitian ini perpanjangan pengamatan dilakukan dengan cara peneliti kembali ke lapangan lagi mengamati proses pelayanan sirkulasi peminjaman dan pengembalian dengan menerapkan sistem otomasi IBRA V6 serta wawancara secara lebih bebas lagi dengan informan sehingga diperoleh data yang benar-benar sama dengan data awal penelitian. (2) Triangulasi, Menurut Moleong (2017) teknik triangulasi merupakan teknik pemeriksaan validitas data yang memanfaatkan sesuatu yang lain diluar data itu untuk keperluan pengecekan atau pembanding terhadap data. Teknik triangulasi yang banyak digunakan ialah pemeriksaan melalui sumber lainnya. Menurut Sugiyono (2010), Pengecekan data atau triangulasi dibagi menjadi tiga yaitu (a) Triangulasi sumber, dalam penelitian ini triangulasi sumber dilakukan dengan mengecek data melalui berbagai sumber penelitian yang ada meliputi informan yang didapat dari wawancara kemudian observasi atau pengamatan langsung serta dokumentasi berupa buku panduan maupun foto-foto. Berdasarkan data yang telah diperoleh dari berbagai sumber tersebut selanjutnya peneliti menganalisis data dan membuat kesimpulan dari penelitian yang telah dilakukan. (b) Triangulasi teknik, dalam hal ini peneliti akan melakukan wawancara secara semi struktur terlebih dahulu yaitu dengan bantuan pedoman wawancara, kemudian peneliti melakukan observasi secara langsung untuk memastikan dengan hasil wawancara dan peneliti melakukan wawancara secara bebas untuk mendapatkan data secara mendalam. (c) Triangulasi waktu, dalam penelitian ini peneliti melakukan wawancara pada siang hari pada waktu istirahat tiba, kemudian peneliti melakukan wawancara pada pagi hari dengan harapan informan masih fresh sehingga data yang diperoleh semakin valid dan reliabel. (3) Membercheck, Sugiyono (2010) mengatakan bahwa Membercheck merupakan suatu proses pengecekan data yang diperoleh peneliti kepada pemberi data. Tujuan membercheck adalah untuk mengetahui seberapa jauh data yang diperoleh sesuai dengan apa yang diberikan oleh pemberi data. Dalam penelitian ini peneliti akan melakukan pengecekan setelah pengumpulan data selesai yaitu dengan mengkonfirmasikan kepada pemberi data yang satu dengan yang lainnya. Apabila data yang ditemukan telah disepakati oleh pemberi data, maka datanya semakin valid dan reliabel berarti semakin dapat dipercaya. 
Namun, apabila data yang ditemukan peneliti menimbulkan beberapa penafsiran maka peneliti akan merubah hasil penemuannya dan menyesuaikan dengan apa yang diberikan oleh pemberi data.

\section{HASIL DAN PEMBAHASAN}

Kegiatan pelayanan koleksi pada temu kembali informasi, penerapan teknologi informasi sangat bermanfaat. Aktivitas tersebut tidak terbatas pada cara penyimpanan buku atau dokumen secara teratur dan tepa, tetapi juga meliputi pemahaman tentang penempatan informasi yang telah diolah dengan tepat agar mudah ditemukan kembali (Rahmawati, 2015). Sebagai lembaga atau unit penyedia informasi, perpustakaan menyajikan materi informasi baik berupa buku maupun dokumen lain yang dimiliki dengan cara menelusur melalui sarana temu kembali berupa katalog, bibliografi maupun indeks. Pencarian informasi akan kesulitan dan membutuhkan waktu yang lama tanpa menggunakan alat penelusur koleksi tersebut. Dalam kaitannya dengan adanya perkembangan teknologi dan informasi, alat penelusur koleksi juga telah di desain menggunakan sistem otomasi perpustakaan yang dirancang dalam sebuah program komputer.

Kemampuan dari sebuah program komputer yang dirancang secara khusus untuk menemukan kembali koleksi yang dicocokkan dengan kata kunci pencarian sangatlah handal. Apalagi, jika program tersebut didukung oleh database yang disusun secara baik maka tingkat kemampuan pencarian dari teknologi tersebut semakin meningkat (Kusnandar \& Yusup, 2015). Penerapan teknologi informasi di Perpustakaan SDIT Luqman Al-Hakim Internasional Yogyakarta diharapkan mampu untuk melakukan pencarian dan meningkatkan pelayanan. Penelitian ini dimaksudkan untuk mendeskripsikan proses sirkulasi dengan menerapkan sistem otomasi perpustakaan berbasis IBRA V6 di Perpustakaan SDIT Luqman Al-Hakim Internasional Yogyakarta. Selain itu juga bermaksud untuk mengetahui penyebab masih digunakannya sistem manual pada layanan sirkulasi padahal sudah terotomasi dan diharapkan akan diperoleh solusi dari masalah tersebut. Indikator yang digunakan dalam penelitian ini mengacu pada teori tentang kinerja layanan yang dikemukakan oleh Sutarno (2006) dalam Siregar (2017) kemudian diformulasikan dengan teori tentang kesuksesan sistem oleh DeLone \& McLean (D\&M IS Success Model). Kedua formulasi teori tersebut dimaksudkan untuk mendapatkan data yang valid tentang kinerja sistem otomasi terhadap layanan sirkulasi.

Berdasarkan hasil analisis data menggunakan metode dokumentasi, observasi dan wawancara terhadap para informan, maka diperoleh hasil evaluasi dari beberapa indikator kinerja sistem otomasi perpustakaan pada proses peminjaman dan pengembalian koleksi di Perpustakaan Adiba SDIT Luqman AlHakim Internasional sebagai berikut. Indikator masukan (input) dimaksudkan untuk mengukur sumberdaya perpustakaan, baik yang bersifat fisik (material) seperti koleksi, sarana prasarana, sumber dana serta perabotan, maupun yang bersifat nonfisik (immaterial) seperti kebijakan, peraturan dan perundangundangan serta yang lainnya yang digunakan untuk melaksanakan kegiatan. Sarana dan prasarana untuk menunjang kinerja sistem di perpustakaan ini mencakup seperangkat komputer yang sudah terinstal IBRA V6, barcode scanner serta printer, sudah memadai. Untuk ukuran perpustakaan SD apalagi luas ruangan Perpustakaan SDIT Luqman AlHakim Internasional yang berukuran $6 \times 5$ $\mathrm{m}^{2}$ sudah cukup menggunakan seperangkat komputer, printer serta satu scanner untuk peminjaman dan pengembalian koleksi. Ruangan yang terbatas tidak memungkinkan untuk 
penambahan perlengkapan lagi, selain itu pustakawan yang melayani sirkulasi hanya ada satu orang dan untuk pemustaka juga masih sanggup jika dilayani dengan perlengkapan tersebut. Meskipun sarana dan prasarana untuk menunjang kinerja otomasi sudah memadai, namun diperlukan ruangan yang standar atau yang lebih besar dari ruangan yang saat ini digunakan. Hal tersebut bertujuan untuk menunjang pelayanan yang lain agar semakin optimal.

Sedangkan untuk tenaga yang ada di Perpustakaan Adiba SDIT Luqman AlHakim Internasional juga sudah memadai. Karena ukuran perpustakaannya yang kecil dan pemustakanya sekitar 300 orang, maka dengan tenaga dua orang staf sudah memenuhi untuk menjalankan programprogramnya. Namun, untuk masalah yang saat ini muncul yaitu kehilangan data dalam sistem otomasi sehingga menjadikan pelayanan sirkulasi peminjaman dan pengembalian dilakukan secara manual, maka dibutuhkan tenaga sementara untuk membantu menginput koleksi perpustakaan agar dapat segera dilayankan dengan otomasi kembali.

Indikator yang kedua adalah proses, dalam hal ini yaitu kualitas sistem yang digunakan serta operasionalnya. Kualitas sistem meliputi keakuratan data, kelengkapan sistem serta kecepatan layanan. Berdasarkan wawancara yang telah dilakukan kepada informan, dapat diketahui bahwa setelah menerapkan IBRA V6 pada proses sirkulasi peminjaman dan pengembalian di Perpustakaan Adiba SDIT Luqman AlHakim Internasional, keakuratan data sudah akurat khususnya dalam hal temu kembali informasinya.

"Setelah menggunakan IBRA ini, keakuratan data meningkat khususnya dalam hal temu kembali informasi. Sangat berbeda saat masih menggunakan manual, kalau manual datanya sering salah, apalagi dulu kan siswa menulis sendiri kalau pinjam buku dan saya kesulitan membacanya" (U. Lia, wawancara, Februari 29, 2016).

Hal ini diperkuat dengan hasil observasi, bahwa pencarian data yang diinginkan oleh pemustaka sesuai dengan data yang ada di dalam sistem. Berbeda dengan saat masih menggunakan manual, pustakawan kesulitan untuk menemukan koleksi karena harus melihat satu per satu peminjaman pada buku peminjaman.

Untuk kelengkapan sistemnya, sistem IBRA V6 ini sudah lengkap khususnya dalam modul sirkulasinya. Dalam modul ini terdapat beberapa menu antara lain transaksi, pustaka cetak, anggota, OPAC (Online Public Access Catalog) serta laporan. Menu utama yang digunakan untuk melakukan pelayanan sirkulasi yaitu menu transaksi, namun dalam modul sirkulasi ini tidak hanya disediakan menu transaksi saja melainkan menu untuk pengolahan pustaka, keanggotaan hingga OPAC. Hal ini mempermudah pustakawan untuk mengkoordinasikan apabila akan mencari koleksi atau anggota untuk melakukan peminjaman karena berada dalam satu modul, yaitu sirkulasi. Sehingga tidak perlu terlebih dahulu keluar dari menu sirkulasi dan mencari menu lain, namun sudah tersedia dalam satu modul tersebut.

Kecepatan pelayanan khususnya peminjaman dan pengembalian dengan menggunakan sistem otomasi IBRA V6 ini semakin meningkat. Sehingga tidak terjadi lagi antrian peminjaman yang dapat menghambat pelayanan sirkulasi. Pustakawan hanya butuh men-scan kartu anggota dan barcode yang sudah ditempel pada buku dengan menggunakan scanner. Berbeda dengan menggunakan manual, pustakawan harus menulis secara detail mulai dari judul buku yang akan dipinjam, nama peminjam, tanggal pinjam dan tanggal pengembalian, selain itu juga harus menuliskan kembali dalam kartu buku yang berada di belakang buku. Jadi, kecepatan pelayanan khususnya peminjaman dan pengembalian dengan menggunakan sistem otomasi IBRA V6 ini semakin meningkat. 
Operasional dari sistem otomasi IBRA V6 ini mudah. Karena menu-menu yang digunakan mudah dipahami dan mudah dijalankan. Secara umum fiturfitur IBRA V6 sederhana dan mudah digunakan. Semua menu tampak jelas dan tidak ada yang tersembunyi. Namun bagi orang yang belum terbiasa atau tidak telaten mungkin hal seperti ini masih sulit dilakukan. Seperti bagi kepala Perpustakaan Adiba ini sendiri. Karena jarang menggunakan atau menjalankan program IBRA tersebut, maka kesulitan saat mengoperasikan untuk pelayanan.

Indikator yang ketiga yaitu keluaran (output). Dengan menerapkan sistem otomasi berbasis IBRA V6 pada proses sirkulasinya, maka pelayanan menjadi lebih efektif dan efisien dan secara tidak langsung, adanya sistem ini menjadi daya tarik tersendiri bagi para siswa yang berkeingintahuan tinggi sehingga pengguna perpustakaan semakin meningkat. Mulanya siswa penasaran dengan alat scanner dan sistem otomasinya, kemudian mereka berinisiatif untuk meminjam buku hingga menjadi kebiasaan.

Proses sirkulasi peminjaman dan pengembalian koleksi yang terjadi di Perpustakaan SDIT Luqman Al-Hakim Internasional saat ini ada dua sistem yaitu secara manual dan sirkulasi. Hal tersebut disebabkan data yang telah terinput kedalam sistem telah hilang karena harddisk yang digunakan untuk menyimpan data rusak dan data tersebut belum di backup. Sehingga untuk sementara, selama data belum dimasukkan ke dalam sistem, pelayanan dilakukan secara manual. Sedangkan jika koleksi sudah diinput maka pelayanan dilakukan menggunakan sistem otomasi. Namun kebanyakan koleksi belum diinput sehingga pelayanan sering menggunakan manual daripada otomasi. Untuk itu, hingga saat ini masih berlangsung penginputan ulang koleksi ke dalam sistem otomasi IBRA V6.
Dampak atau outcome yang dihasilkan dengan adanya sistem otomasi IBRA V6 di Perpustakaan SDIT Luqman Al-Hakim Internasional ini sangat dirasakan baik bagi pustakawan maupun pemustakanya. Pelayanan yang dilakukan dapat berlangsung lebih singkat dari pada sebelum menggunakan sistem otomasi ini. Selain itu sudah tidak terjadi antrian panjang ketika banyak pemustaka yang akan meminjam koleksi. Namun karena sistem ini masih berbayar dan bukan open source, maka segala kerusakan atau eror sistem masih tergantung kepada pihak pengelola. Jadi perpustakaan harus mendatangkan pihak pengelola atau dalam hal ini Teratama untuk memperbaiki sistem ketika terjadi eror. Ketergantungan terhadap pihak Teratama ini menjadi kendala tersendiri khususnya dalam hal anggaran. Hal ini dikarenakan setiap mendatangkan pengelola untuk memperbaiki sistem, perpustakaan selalu mengeluarkan anggaran tersendiri lagi, bukan termasuk anggaran pemasangan atau instalasi sistem.

Masalah lain semenjak diterapkannya sistem otomasi perpustakaan ini yaitu adanya dualisme sistem pelayanan sirkulasi yang digunakan. Mulai bulan Januari 2016 sampai saat ini, Perpustakaan SDIT Luqman Al-Hakim Internasional mengalami dualisme sistem pelayanan sirkulasi yaitu manual dan otomasi. Otomasi sudah ada namun manual masih digunakan karena adanya kerusakan pada harddisk, sehingga data yang telah diinput hilang semuanya. Hal tersebut terjadi mula-mula komputer tidak bisa dinyalakan lagi. Hingga waktu beberapa hari, akhirnya pustakawan menghubungi pihak IBRA dan diketahui bahwa harddisk yang digunakan untuk menyimpan data otomasi telah rusak. Salah satu faktor yang menyebabkan kerusakan harddisk yaitu sering matinya listrik atau stabilizator secara tiba-tiba. Sering matinya listrik tersebut disebabkan oleh penggunaan daya listrik yang tidak teratur karena 
terjadi perebutan daya dengan guru kelas yang memakai proyektor di dalam kelas tanpa konfirmasi dahulu dengan perpustakaan.

Data yang sebelumnya telah diinput dan dilayankan dengan otomasi belum dilakukan back-up sehingga ketika terjadi kerusakan maka data tersebut hilang. Untuk melayankan kembali dengan otomasi, pustakawan harus menginput dahulu data-data koleksi kedalam sistem. Oleh karena itu, sambil menunggu data terinput semua, sementara pelayanan sirkulasi dibagi menjadi dua. Data yang sudah diinput langsung bisa dilayankan dengan menggunakan sistem, sedangkan data yang telah hilang dan belum diinput dilayankan dengan menggunakan manual. Hal ini yang menyebabkan penggunaan dualisme sistem pelayanan sirkulasi di Perpustakaan SDIT Luqman Al-Hakim Internasional Yogyakarta. Kondisi ini dilakukan untuk sementara waktu saja hingga data koleksi dapat terinput seluruhnya kedalam sistem IBRA V6. Penggunaan sistem otomasi yang masih tumpang tindih dengan sistem manual ini tetap dilakukan dengan tujuan untuk mendapatkan pelaporan statistik yang lebih rinci berkaitan dengan peminjaman dan pengembalian, serta pelaporan status koleksi. Selain itu juga untuk mempersingkat waktu pelayanan sirkulasi di perpustakaan.

Selain rusaknya harddisk, penyebab lain mengenai masih digunakannya sistem manual padahal sudah terotomasi berupa nonteknis yaitu karena kurangnya kesiapan sumber daya manusia dalam melakukan pelayanan secara otomasi. Sebagian besar koleksi yang datanya hilang belum diinput kembali, karena untuk menginput kembali koleksi tersebut membutuhkan waktu dan tenaga yang lebih. Hal ini mengingat bahwa pustakawan juga mempunyai banyak tugas yang lain. Meskipun baru sebagian kecil koleksi yang telah di-input, namun pustakawan tetap menggunakan pelayanan dengan sistem otomasi untuk koleksi yang sudah diinput. Penginputan koleksi dilakukan dengan memilih koleksi-koleksi perpustakaan yang sering dipinjam oleh pemustaka. Koleksi ini biasanya berupa buku-buku cerita fiksi, dongeng, hingga komik. Jadi proses input koleksi diutamakan koleksi kesusastraan.

Kendala utama dalam perpus-takaan yaitu adanya koleksi yang belum di-input kedalam sistem namun sudah dilayankan, sehingga pelayanannya menggunakan manual padahal sudah terotomasi. Jika koleksi tersebut akan di-input terlebih dahulu ke dalam sistem secara keseluruhan, koleksi tersebut sudah dibutuhkan oleh pemustakanya. Oleh karena itu terjadilah penggunaan dua sistem (dualisme sistem) pada layanan sirkulasinya. Kendala lainnya ialah ruangannya yang hanya berukuran $6 \times 5 \mathrm{~m}^{2}$ untuk menampung koleksi sekitar 5.000 eksemplar. Sedangkan untuk kendala khusus untuk kinerja sistem otomasi IBRA ini karena kurangnya koordinasi atau informasi-informasi penting dengan pihak IBRA. Namun hal tersebut mungkin karena sistem otomasi ini berbayar sehingga dari pihak IBRA tidak memberikan pengajaran seluruhnya mengenai hal-hal yang ada di dalam sistem tersebut.

\section{SIMPULAN}

Berdasarkan pembahasan yang telah diuraikan, peneliti mendapatkan hasil bahwa evaluasi kinerja sistem otomasi berbasis IBRA V6 pada pelayanan sirkulasi di Perpustakaan SDIT Luqman Al-Hakim 
Internasional dengan menggunakan indikator-indikator evaluasi sistem sudah baik. Kinerja sistem otomasi perpustakaan berbasis IBRA V6 dievaluasi berdasarkan formulasi teori tentang kinerja layanan yang dikemukakan oleh Sutarno (2006) dalam Siregar (2017) dengan teori tentang kesuksesan sistem oleh DeLone \& McLean (D\&M IS Success Model). Dari keduanya didapatkan 5 indikator yang meliputi sarana pendukung, kualitas sistem, operasional, layanan, serta dampak yang ditimbulkan. Dari kelima indikator tersebut dapat digolongkan kedalam tiga kategori yaitu masukan, proses dan keluaran. Diperoleh bahwa sarana pendukung sudah memadai hanya saja ruangannya yang sempit sehingga pelayanan keseluruhan kurang maksimal. Sedangkan indikator yang lain diperoleh hasil baik, efektif dan efisien. Secara keseluruhan penggunaan teknologi dan informasi di perpustakaan memberikan kemudahan akses dan layanan baik bagi pustakawan maupun pemustakanya. Sedangkan kendala khusus dalam penerapan otomasi IBRA V6 yaitu kurangnya koordinasi atau informasiinformasi penting antara perpustakaan dengan pihak pengelola. Sehingga untuk kedepannya diperlukan kerjasama yang lebih baik lagi antara pustakawan dengan pihak pengelola IBRA, mengingat bahwa sistem ini tidak bersifat opensource.

\section{DAFTAR PUSTAKA}

Arikunto. (2010). Prosedur penelitian: suatu pendekatan praktek. Jakarta: Rineka Cipta.

Azwar, M. (2015). Penerapan sistem otomasi di Perpustakaan Fakultas Adab dan Humaniora UIN Alauddin Makassar. Jurnal AlKuttab: Jurnal Perpustakaan Dan Informasi, 2(1), 45-67. Retrieved from http://e-

journal.perpustakaanstainpsp.net/i ndex.php/alkuttab/article/view/51

Dana, T., Samosir, D. H., \& Widiyasa, I. M. (2015). Pengembangan digital library perpustakaan Universitas Atmajaya Yogyakarta. In Seminar Nasional Informatika (SEMNASIF).

Hasanah, U. (2010). Preservasi bahan pustaka di Perpustakaan UIN Sunan Kalijaga Yogyakarta. Skripsi. Universitas Islam Negri Sunan Kalijaga, Yogyakarta.

Kusnandar, \& Yusup, P. M. (2015). Pengembangan modul public users pada Sistem Informasi Kearsipan Akademik Elektronik (studi action research pengembangan modul public users pada Sistem Informasi Kearsipan Akademik Elektronik (SiAMEL) di Fakultas Ilmu Komunikasi Universitas Padjadjaran). Jurnal Kajian Informasi $\mathcal{E}$ Perpustakaan, 3(1), 1-8. https://doi.org/10.24198/jkip.v3i1. 9351

Lasa, H. S. (2009). Kamus kepustakawanan Indonesia. Yogyakarta: Pustaka Book Publisher.

Lasa, H. S. (2013). Manajemen perpustakaan sekolah. Yogyakarta: Pinus Book Publisher.

Moleong, L. J. (2017). Metode penelitian kualitatif. Bandung: Remaja Rosdakarya.

Purwanto, A. J. (2015). Otomasi perpustakaan di Perpusda Kudus menggunakan Senayan Library. LIBRARIA: Jurnal Perpustakaan, 3(2), 256-286. Retrieved from http:/ /journal.stainkudus.ac.id/ind ex.php/Libraria/article/view/1598

Rahardjo, M. (2017). Studi kasus dalam penelitian kualitatif: konsep dan prosedurnya. Skripsi. UIN Maulana Malik Ibrahim, Malang.

Rahmawati, N. H. (2015). Upgrading sistem informasi pusat 
Perpustakaan IAIN Surakarta: dari Sistem Perpustakaan (Siprus) ke Library System (LIBSYS). LIBRARIA: Jurnal Perpustakaan, 3(2), 247-264. Retrieved from http://journal.stainkudus.ac.id/ind ex.php/Libraria/article/view/1596

Wakhid, A., Sitanggang, I.S., \& Saleh, A.R. (2016). Rancangan sistem penilaian kinerja perpustakaan berbasis indikator kinerja ISO 11620: 2008 pada layanan terbuka Perpustakaan Nasional RI. Jurnal Pustakawan Indonesia, 14(2), 1-13. Retrieved from http://journal.ipb.ac.id/index.php/ jpi/article/view/13716

Rodin, R. (2015). Urgensi kualitas pelayanan perpustakaan perguruan tinggi. Jurnal Al-Kuttab: Jurnal Perpustakaan Dan Informasi, 2(1), 120. Retrieved from http://jurnal.unpad.ac.id/jkip/artic le/view/10274

Saputra, D., Cahyadi, D., \& Kridalaksana, A. H. (2016). Sistem otomasi pepustakaan dengan menggunakan Radio Frequency Identification (RFID). Informatika Mulawarman, 5(3), 1-7. Retrieved from http://ejournals.unmul.ac.id/index.php/JI $\mathrm{M} /$ article/view/62

Siregar, B. G. (2017). Implementasi manajemen perpustakaan berbasis teknologi untuk percepatan pelayanan. Jurnal Al-Kuttab: Jurnal Perpustakaan Dan Informasi, 4(1), 16 32. Retrieved from http://ejournal.perpustakaanstainpsp.net/i ndex.php/alkuttab/article/view/44 3

Sugiyono. (2010). Metode penelitian kuantitatif, kualitatif dan RED. Bandung: Alfabeta.

Sulistyo-Basuki. (2010). Pengantar ilmu perpustakaan. Jakarta: PT. Gramedia Pustaka Utama.

Teratama Technology System. (2014). Modul Teratama IBRA V6. Yogyakarta: Teratama Technology System.

Wisudiawan, G. A. A. (2015). Analisis faktor kesuksesan sistem informasi menggunakan model DeLone and McLean. Jurnal Ilmiah Teknologi Informasi Terapan, 2(1), 55-59. Retrieved from http://jitter.widyatama.ac.id/index. $\mathrm{php} /$ jitter/article/view/66 
